\title{
MDR1 gene-related clonal selection and P-glycoprotein function and expression in relapsed or refractory acute myeloid leukemia
}

Marry M. van den Heuvel-Eibrink, Erik A. C. Wiemer, Marjan J. de Boevere, Bronno van der Holt, Paula J. M. Vossebeld, Rob Pieters, and Pieter Sonneveld

The expression of P-glycoprotein ( $P$ $\mathrm{gp})$, encoded by the MDR1 gene, is an independent adverse prognostic factor for response and survival in de novo acute myeloid leukemia (AML). Little is known about MDR1 expression during the development of disease. The present study investigated whether MDR1 generelated clonal selection occurs in the development from diagnosis to relapsed $A M L$, using a genetic polymorphism of the MDR1 gene at position 2677. Expression and function of P-gp were studied using monoclonal antibodies MRK16 and UIC2 and the Rhodamine 123 retention assay with or without PSC 833. No difference was found in the levels of P-gp function and expression between diagnosis and relapse in purified paired blast samples from 30 patients with AML. Thirteen patients were homozygous for the genetic polymorphism of MDR1 ( $\mathrm{n}=7$ for guanine, $n=6$ for thymidine), whereas 17 patients were heterozygous (GT). In the heterozygous patients, no selective loss of one allele was observed at relapse. Homozygosity for the MDR1 gene (GG or TT) was associated with shorter relapsefree intervals $(P=.002)$ and poor survival rates $(P=.02)$, compared with heterozy- gous patients. No difference was found in P-gp expression or function in patients with AML with either of the allelic variants of the MDR1 gene. It was concluded that $P$-gp function or expression is not upregulated at relapse/refractory disease and expression of one of the allelic variants is not associated with altered P-gp expression or function in AML, consistent with the fact that MDR1 gene-related clonal selection does not occur when AML evolves to recurrent disease. (Blood. 2001;97:3605-3611)

() 2001 by The American Society of Hematology

\section{Introduction}

Classic multidrug resistance (MDR) encoded by the MDR 1 gene is characterized by expression of P-glycoprotein (P-gp), which acts as a drug efflux pump in the plasma membrane. Expression of $M D R 1$ has been identified as an independent adverse prognostic factor for complete remission (CR) and survival in patients with acute myeloid leukemia (AML), especially in adults..$^{1-11}$ Little is known about possible changes in MDR1 gene expression during the development to relapse or refractory disease, especially in paired analyses of clinical samples of patients with AML. It is conceivable that $M D R 1$ positive clones develop by clonal selection during chemotherapy or by $M D R 1$ gene activation. This phenomenon has been described for Burkitt lymphoma, in which single allelic $M D R 1$ expression was found to be up-regulated during the development of disease. ${ }^{12}$

In the present study, we investigated whether clonal selection of one MDR 1 allele contributes to drug resistance in AML, by studying the genetic polymorphism of the MDR 1 gene at position $2677.1^{13}$ This study was performed in paired samples of patients with AML at time of diagnosis and at first relapse or refractory disease. In addition, an analysis was performed of the expression and function of P-gp. To the best of our knowledge, no previous studies have been reported in which the P-gp levels were measured in the allelic variants of the $M D R 1$ gene.

\section{Patients and methods}

\section{Patients}

Bone marrow samples from 30 patients with AML (9 children, 21 adults) were obtained from the iliac crest at diagnosis and at time of first relapse $(n=27)$ or refractory disease $(n=3)$ (Table 1$)$. Written informed consent was obtained from each patient and/or their parents to perform these studies. AML classification, according to the French-American-British (FAB) criteria ${ }^{14}$ was M1 $(\mathrm{n}=8)$, M2 $(\mathrm{n}=11)$, M4 $(\mathrm{n}=2)$, M5 $(\mathrm{n}=7)$, and M6 $(n=2)$. Cytogenetic analysis was carried out by standard techniques, and the findings were described according to the international nomenclature. ${ }^{15}$ Patients with a deletion or loss of chromosome 7 were not included in the study, because of the (possible) loss of one MDR 1 gene which is located on $7 \mathrm{q} 21.1$, which complicates the analysis of polymorphism in these patients. All patients were treated according to the Helsinki agreement and were included in treatment protocols of the Dutch-Belgian Hemato-Oncology Collaborative Group (protocol HOVON 4/4a resp. HOVON 29) for young adults $(n=17)$, European Organisation for Research and Treatment of Cancer (EORTC protocol LAM 9) $(n=1)$ for patients 60 years or older, and the Dutch Childhood Leukemia Study Group (DCLSG: protocol ANLL 87 and 94) $(\mathrm{n}=9)$ for children (younger than 18 years old). After relapse or in case of refractory disease after induction therapy, adults were treated according to the HOVON 30 protocol. The pediatric patients received treatment according to institutional protocols (Table 2). For some patients, individual therapy choices were made (Table 1). CR
From the Department of Hematology, University Hospital; the Department of Pediatric Oncology/Hematology, Sophia Children's Hospital; the Department of Statistics, Daniel den Hoed Cancer Centre, Erasmus University, Rotterdam; and The Dutch Childhood Leukemia Study Group, The Hague, The Netherlands.

Submitted October 10, 2000; accepted January 31, 2001.

Supported by the Sophia Foundation for Medical Research (SSWO grant 246), the Foundation Pediatric Oncology Centre Rotterdam (Stichting SKOR), and the Kröger Society.
Reprints: M. M. van den Heuvel-Eibrink, Sophia Children's Hospital, Department of Oncology/Hematology, Rm Sp 2429, Dr Molewaterplein 60, 3015 GJ Rotterdam, The Netherlands; e-mail: vandeheuvel@alkg.azr.nl.

The publication costs of this article were defrayed in part by page charge payment. Therefore, and solely to indicate this fact, this article is hereby marked "advertisement" in accordance with 18 U.S.C. section 1734

C 2001 by The American Society of Hematology 
Table 1. Clinical characteristics of 30 patients with acute myeloid leukemia

\begin{tabular}{|c|c|c|c|c|c|c|c|}
\hline \multirow[b]{2}{*}{ Patient } & \multirow[b]{2}{*}{$\begin{array}{c}\text { Expression of } M D R 1 \\
\text { gene polymorphism } \\
\text { (G/T variant) }\end{array}$} & \multicolumn{4}{|c|}{ Diagnosis } & \multicolumn{2}{|c|}{ Relapse/Refractory disese } \\
\hline & & $\begin{array}{c}\text { Age } \\
\text { (years) }\end{array}$ & $\begin{array}{c}\mathrm{FAB} \\
\text { classification }\end{array}$ & Karyotype & $\begin{array}{l}\text { Relapse free } \\
\text { after 1st CR } \\
\text { (months) }\end{array}$ & $\begin{array}{c}\text { Treatment } \\
\text { (at time of relapse/ } \\
\text { refractory disease) }\end{array}$ & $\begin{array}{c}\text { Response } \\
\text { (to reinduction) }\end{array}$ \\
\hline 1 & GT & 2 & M5 & Unfavorable & 8 & NT & \\
\hline 2 & $\mathrm{G}$ & 1 & M6 & Neutral & 4 & 2cdA/Ara-C/Idarubicin & No CR \\
\hline 3 & GT & 47 & M2 & Neutral & 50 & HOVON30 & $\mathrm{CR}$ \\
\hline 4 & $\mathrm{~T}$ & 55 & M2 & Neutral & - & HOVON30 & No $\mathrm{CR}^{\star *}$ \\
\hline 5 & $\mathrm{~T}$ & 50 & M5 & Neutral & 25 & HOVON30 & CR \\
\hline 6 & GT & 50 & M2 & Neutral & 7 & HOVON30 & $\mathrm{CR}$ \\
\hline 7 & GT & 62 & M1 & Unfavorable & 31 & HOVON30 & $\mathrm{CR}$ \\
\hline 8 & GT & 61 & M1 & Neutral & 29 & HOVON30 & No CR \\
\hline 9 & GT & 35 & M1 & Favorable & 12 & HOVON30 & $\mathrm{CR}$ \\
\hline 10 & GT & 9 & M5 & Unfavorable & 9 & NT & \\
\hline 11 & GT & 12 & M1 & Neutral & 33 & DCLSG ANLL94 & CR \\
\hline 12 & GT & 37 & M1 & Neutral & 12 & HOVON29 & $\mathrm{CR}$ \\
\hline 14 & $\mathrm{G}$ & 46 & M5a & Neutral & 6 & NT & \\
\hline 15 & GT & 67 & M2 & Neutral & 9 & EORTC 9 & No CR \\
\hline 16 & $\mathrm{~T}$ & 16 & M4eo & Favorable & 8 & HOVON29 & CR \\
\hline 17 & GT & 19 & M5a & Neutral & 28 & HOVON29 & No CR \\
\hline 18 & GT & 42 & M2 & Neutral & 11 & HOVON29 & $\mathrm{CR}$ \\
\hline 19 & GT & 1 & M1 & Neutral & 14 & DCLSG ANLL87 & No CR \\
\hline 20 & $\mathrm{G}$ & 41 & M6 & Neutral & 4 & HOVON30 & $\mathrm{CR}$ \\
\hline 21 & GT & 10 & M2 & Favorable & 58 & DCLSG ANLL94 & CR \\
\hline 22 & $\mathrm{~T}$ & 63 & M2 & Neutral & 20 & NT & \\
\hline 23 & $\mathrm{G}$ & 1 & M5 & Unfavorable & 10 & DCLSG ANLL87 & No CR \\
\hline 24 & GT & 27 & M2 & Neutral & 14 & HOVON30 & $\mathrm{CR}$ \\
\hline 25 & $\mathrm{G}$ & 34 & M5 & Neutral & - & HOVON30 & No $\mathrm{CR}^{\star \star}$ \\
\hline 26 & GT & 5 & M1 & Neutral & 18 & DCLSG ANLL87 & $\mathrm{CR}$ \\
\hline 27 & $\mathrm{G}$ & 18 & M2 & Neutral & 8 & Mitoxantrone & No CR \\
\hline 28 & $\mathrm{~T}$ & 55 & M1 & Neutral & - & HOVON30 & No $\mathrm{CR}^{* *}$ \\
\hline
\end{tabular}

$\mathrm{CR}$ indicates complete remission after 1 or 2 courses of reinduction chemotherapy; No CR, refractory disease at time of relapse, No $\mathrm{CR}^{\star *}$ indicates never $\mathrm{CR}^{*}$ after diagnosis; NT, not treated for relapse. For karyotypes, unfavorable indicates $\mathrm{t}(9 ; 22), 11 \mathrm{q} 23$ with $M L L$ rearrangements, complex karyotype, 5q-; favorable indicates inv(16), $t(15 ; 17)$ and $t(8 ; 21)$; and neutral indicates normal and other karyotypes.

status was defined as normocellular marrow with $<5 \%$ blasts in a bone marrow (BM) smear and normal peripheral blood cell counts

\section{Methods}

Patient samples. Bone marrow aspirates were obtained in heparinized tubes. Mononuclear bone marrow cells (MNCs) were collected by Ficoll Hypaque density gradient centrifugation (density $1.077 \mathrm{~g} / \mathrm{m}^{3}$ ) (Pharmacia, Uppsala, Sweden). To obtain purified samples with more than $85 \%$ blasts, T-cell depletion and adherence depletion were performed. ${ }^{16}$ Cells were cryopreserved in Iscoves modified Dulbecco medium (IMDM; Gibco, Paisley, United Kingdom) supplemented with $10 \%$ dimethyl sulfoxide (DMSO; Merck, Darmstadt, Germany) and 20\% fetal calf serum (FCS
Gibco) and stored in liquid nitrogen. On the day of the experiments bone marrow cells were thawed. For flowcytometry experiments, cells were washed and resuspended in IMDM supplemented with 10\% FCS and gentamycin at a concentration of $4 \times 10^{6}$ cells $/ \mathrm{mL}$. Total RNA was isolated using Trisolv extraction (Biotecx, Houston, TX).

Oligonucleotide hybridization and dotblot analysis. Both DNA and RNA were used as templates in the polymerase chain reaction (PCR). One microgram of genomic DNA was used as a template in the PCR for 40 cycles to investigate the genetic polymorphism at the DNA level. One microgram of total RNA was reverse transcribed and the cDNA template was subjected to 40 cycles of PCR. The following primers were used as described by Mickley ${ }^{12,13}$ : 5' 2521 GCAAATCTTGGGACAGGAAT;

Table 2. Cumulative drug doses in the treatment protocols for acute myeloid leukemia

\begin{tabular}{|c|c|c|c|c|c|c|c|c|c|c|c|c|}
\hline Drug & Ara-C & DNR & Adria & Amsa & Ida & VP16 & Mitox & Pred & $6 \mathrm{TG}$ & VCR & $\mathrm{CP}$ & CsA \\
\hline \multicolumn{13}{|l|}{ Induction } \\
\hline HOVON 4/4A & 13400 & 135 & & 360 & & 500 & 50 & & & & & \\
\hline HOVON 29 & 13400 & & & 360 & 36 & 500 & 50 & & & & & \\
\hline DCLSG ANLL87* & 22400 & 180 & 120 & & & 1050 & & 1120 & 2580 & 6 & 1000 & \\
\hline DCLSG ANLL94* & 33400 & & 120 & & 36 & 950 & 20 & 1120 & 2520 & 6 & 1000 & \\
\hline \multicolumn{13}{|l|}{ Reinduction } \\
\hline EORTC 9 & 6000 & 90 & & & & & 50 & & & & & \\
\hline HOVON 30 & & & & & & 500 & 50 & & & & & $\pm 5 \mathrm{mg} / \mathrm{kg}$ \\
\hline
\end{tabular}

(Total cumulative dose in $\mathrm{mg} / \mathrm{m}^{2}$.) Ara-C indicates cytosine arabinoside; Adria, adriamycin; DNR, daunorubicin; Amsa, amsacrine; Ida, idarubicin; VP16, etoposide; Mitox, mitoxantrone; Pred, prednisolone; 6TG, 6-thioguanine; VCR, vincristine; CP, cyclophosphamide; and CsA, cyclosporin A.

*Indicates $+5 \times$ intrathecal Ara-C. 
$3^{\prime}$ RNA, ${ }^{2796}$ CTCCTTTCGTGTGTAGAAAC; $3^{\prime}$, DNA, ${ }^{2681}{ }^{2 C T T C}{ }^{2687}$ CACTCAGTTTGATTT.

Reverse transcriptase treatment preceded amplification in order to evaluate RNA expression. All PCR experiments included controls without DNA or RNA. After amplification of $1 \mu \mathrm{g}$ template, $30 \%$ of the PCR product was loaded in each of 2 adjacent wells of a slot-blot apparatus. The Zeta Probe nylon filter (Biorad, Hercules, CA) was cut out into 2 halves and each half was hybridized with a different oligonucleotide. Two 19-bp allele-specific oligonucleotide probes (HMO7 and HMO8) were 5' phosphorylated with $\left[\gamma^{32} \mathrm{P}\right]-\mathrm{ATP}$ and $\mathrm{T}_{4}$ polynucleotide kinase. $\mathrm{HMO} 7$ and HMO8 cover residues 2667 to 2685 and were used for hybridizations. $\mathrm{HMO} 7$ possessess a $\mathrm{G}$ at position 2677 and $\mathrm{HMO} 8$ contains a $\mathrm{T}$ at the same position. Internal controls for hybridization and specificity were included in all experiments. For this purpose, two 30-bp oligonucleotides, designated HMC3 and HMC4, were used. These oligonucleotides cover residues 2656 to 2685 of the MDR 1 gene with HMC3 possessing a $\mathrm{G}$ at position 2677 and HMC4 a T at the same position. Equal amounts of each control were spotted on both sides of the filter. Because the hybridizations were performed under identical conditions, with probes labeled to similar specific activities, the signals from the control oligonucleotides were similar. For quantification of the hybridization spots, the blots were exposed to a Phosfor Imager screen (Molecular Dynamics, Sunnyvale, CA).

Expression of P-glycoprotein. For measurement of the expression of P-gp, cells were incubated at room temperature with the monoclonal anti-P-gp antibodies MRK16 ${ }^{17}$ (Kamiya Biomedical, Tukwila, WA) at a concentration of $10 \mu \mathrm{g} / \mathrm{mL}$ and also, in separate tubes, with UIC2 ${ }^{18}$ (Immunotech, Marseille, France) at a concentration of $12.5 \mu \mathrm{g} / \mathrm{mL}$ or with an isotype-matched mIgG2a control antibody (Sigma, St Louis, MO) at a concentration of $10 \mu \mathrm{g} / \mathrm{mL}$. Cell-bound antibodies were detected by fluorescein isothiocyanate (FITC)-labeled rabbit antimouse immunoglobulin antibodies (Dako, Glostrup, Denmark). Results are given as the ratio of the mean fluorescence of cells incubated with the anti-P-gp antibody divided by the mean fluorescence of cells incubated with the control $\mathrm{mIgG} 2 \mathrm{a}$ antibody. To measure the expression of P-gp in CD34-positive cells, cells were labeled with phyco-erythrin-Cy5-labeled CD34 antibody or a phycoerythrin-Cy5-labeled matched mIgG1 antibody (Immunotech).

Function of P-glycoprotein. For measurement of the function of P-gp, the fluorescent molecule Rhodamine 123 (Rho 123) (Sigma) was used as a P-gp substrate. ${ }^{19,20}$ Cells were incubated for 1 hour at $37^{\circ} \mathrm{C}$ at $5 \% \mathrm{CO}_{2}$ in the absence or presence of $2 \mu \mathrm{M}$ of the P-gp modulator PSC 833 (Novartis, Basel, Switzerland). After this incubation, $200 \mathrm{ng} / \mathrm{mL}$ Rho 123 was added to the cells. A sample was taken at $\mathrm{t}=0$ minutes to correct for background fluorescence and at $\mathrm{t}=75$ minutes to measure intracellular Rho 123 retention. Results were calculated as the PSC/Rho 123 retention ratio of the mean intracellular Rho 123 fluorescence of cells exposed to PSC 833 divided by the mean intracellular Rho 123 fluorescence of cells not exposed to PSC 833. As controls, the drug-sensitive human myeloma cell line 8226 $\mathrm{S}$ and the drug-resistant P-gp expressing variant 8226 D6 cells ${ }^{21}$ were included in each experiment. Taking all experiments together, the mean ratio of P-gp function of the negative control cell line $8226 \mathrm{~S}$ was $0.91 \pm 0.07$ (mean $\pm \mathrm{SD}$ ). The mean ratio of $\mathrm{P}$-gp function of the positive control cell line 8226 D6 was $7.03 \pm 4.69$ (mean $\pm \mathrm{SD})$.

For analysis of the function of P-gp in CD34-positive cells, cells were labeled with phyco-erythrin-Cy5-labeled CD34 antibody or as a control phycoerythrin-Cy5-labeled mIgG1 antibody (Immunotech). Fluorescence was measured using a FACScalibur flowcytometer (Becton Dickinson, San José, CA). Cells were incubated with $0.1 \mu \mathrm{M}$ TO-PRO-3 (Molecular Probes, Eugene, OR) to exclude nonviable cells in the fuctional and expression studies.

Statistical analysis. Expression and functional levels of P-gp, either at diagnosis or at relapse or refractory disease, were compared between subgroups using the Mann-Whitney test in case of 2 subgroups, and the Kruskal-Wallis test in case of 3 subgroups. Moreover, $M D R 1$ expression at relapse or refractory disease was compared with that at diagnosis using the Wilcoxon matched-pairs signed-ranks test, which was restricted to patients with data available both at diagnosis and at relapse or refractory disease. All $P$ values are 2-sided and a significance level $\alpha=.05$ was used.

\section{Results}

Thirty patients with AML were studied at diagnosis and during the course of their disease. Twenty-seven patients developed a relapse after reaching CR with induction chemotherapy. Three patients were primary refractory to induction chemotherapy (Table 1).

\section{Oligonucleotide hybridization and dotblot analysis}

Oligonucleotide hybridization studies of position 2677 of the MDR 1 gene revealed 7 patients with a $\mathrm{G}$ variant, 6 patients with a $\mathrm{T}$ variant, and 17 patients with a GT variant. The 17 patients with heterozygous expression at diagnosis also showed GT expression at relapse. In these patients, no up-regulation of either allele was noticed during the development of disease at RNA level. Consequently, in this group of patients no evidence of a MDR 1 gene-associated selection of a resistant clone was found.

\section{P-glycoprotein expression and function}

MRK16 expression $(n=27)$ and UIC2 expression $(n=25)$ revealed no differences in P-gp expression at relapse or refractory disease as compared with diagnosis $(P=.14$ and $P=.22$, respectively) (Table 3 ). No difference of MRK16 expression in the CD34-positive subpopulation was found $(\mathrm{n}=11)(P=1.0)$ in the paired analysis. The analysis of UIC2/CD34 in matched pairs showed a trend to a lower expression level $(P=.07)$ in relapsed/ refractory disease as compared with diagnosis, although the number of patients that could be analyzed for UIC2/CD34 was

Table 3. Paired analysis of P-glycoprotein expression and function in patients with acute myeloid leukemia at diagnosis and relapse/refractory disease

\begin{tabular}{|c|c|c|c|}
\hline & $\begin{array}{c}\text { At } \\
\text { diagnosis }\end{array}$ & $\begin{array}{l}\text { At relapse and/or } \\
\text { refractory disease }\end{array}$ & $P$ value \\
\hline \multicolumn{4}{|l|}{$M D R 1$} \\
\hline \multicolumn{4}{|l|}{ MRK16 } \\
\hline Median & 2.16 & 1.83 & .14 \\
\hline Range & $1.22-7.65$ & $1.02-5.55$ & \\
\hline $\mathrm{N}$ & 27 & & \\
\hline \multicolumn{4}{|c|}{ MRK16/CD34+ } \\
\hline Median & 2.77 & 2.28 & 1.00 \\
\hline Range & $1.52-9.27$ & $1.46-9.6$ & \\
\hline $\mathrm{N}$ & 11 & & \\
\hline \multicolumn{4}{|l|}{ UIC2 } \\
\hline Median & 2.37 & 1.74 & .22 \\
\hline Range & $1.47-12.3$ & $0.99-6.39$ & \\
\hline $\mathrm{N}$ & 25 & & \\
\hline \multicolumn{4}{|c|}{ UIC2/CD34+ } \\
\hline Median & 3.5 & 2.42 & .07 \\
\hline Range & $1.51-26.6$ & $0.86-7.34$ & \\
\hline $\mathrm{N}$ & 8 & & \\
\hline \multicolumn{4}{|l|}{ PSC/Rho } \\
\hline Median & 1.13 & 1.10 & .26 \\
\hline Range & $0.87-2.11$ & $0.81-2.19$ & \\
\hline $\mathrm{N}$ & 27 & & \\
\hline \multicolumn{4}{|c|}{$\mathrm{PSC} / \mathrm{Rho} \mathrm{CD} 34^{+}$} \\
\hline Median & 1.43 & 1.22 & .39 \\
\hline Range & $0.98-2.7$ & $0.82-3.26$ & \\
\hline $\mathrm{N}$ & 12 & & \\
\hline
\end{tabular}

For P-gp expression, the monoclonal antibodies MRK 16 and UIC2 were used; for P-gp function, the PSC/Rho 123 retention ratio was used. In samples with greater than $10 \%$ CD34 expression, the variables were also evaluated in the CD34 ${ }^{+}$ subfraction of the blasts. The $P$ values indicate the differences between diagnosis and relapse/refractory disease. 
small $(\mathrm{n}=8)$ (Table 3; Figure 1C). The CD34 expression was not different at relapse as compared to diagnosis $(P=.31)$.

The PSC/Rho 123 retention ratio $(\mathrm{n}=27)$ was not significantly different between diagnosis and relapsed/refractory $\operatorname{AML}(P=.26)$. When analyzed in the CD34-positive subpopulation of blasts $(\mathrm{n}=12)$, comparable results were found $(P=.39)$ (Table 3; Figure 1A). No difference was found in P-gp expression $(P=.67$ for MRK16 expression, $P=.82$ for UIC2 expression) or PSC/Rho ratio $(P=.09)$ at diagnosis nor at relapse/refractory disease $(P$ values of $.42, .67$, and .11 , respectively) between adults and children.

\section{P-glycoprotein versus MDR1 allelic expression}

As the functional meaning of the genetic polymorphism of the $M D R 1$ gene has not been established as yet, we analyzed P-gp in patients with expression of the G, T, and GT variants. The median MRK16 expression ratio was not significantly different in the various allelic variants $(P=.72$ at diagnosis and $P=.34$ at relapse). Also, no difference was found with monoclonal antibody UIC2 $(P=.81$ at diagnosis and $P=.25$ at relapse $)$ and the $\mathrm{PSC} /$ Rho 123 retention ratio $(P=.26$ at diagnosis, $P=.11$ at relapse). No difference was found in P-gp expression or function when homozygous patients were compared with heterozygous patients (Table 4). Similarly, in the CD34-positive fraction we did not find differences in P-gp expression and function between the different $M D R 1$ allelic variants at diagnosis nor at relapse and/or refractory disease. The results show that there is no difference in P-gp expression and function in AML blast cells between the different specific allelic variants of the MDR 1 gene. The therapeutic outcome of patients with the different allelic variants showed a significant difference, that is, homozygosity was associated with a
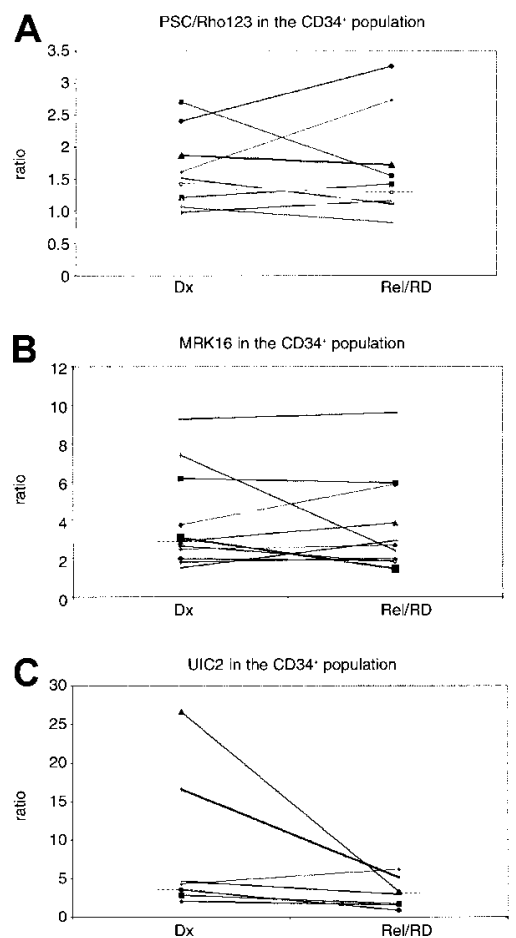

Figure 1. P-glycoprotein expression and function in the CD34-positive population of the paired AML patients. (C) The UIC2 and (B) MRK16 ratios represent the
expression of P-gp, and (A) PSC 833/Rho123 represents the function of P-gp. Dx indicates diagnosis; Rel/RD, relapsed/refractory AML. The dotted lines indicate the median values.
Table 4. Analysis of P-glycoprotein expression and function in the homozygous vs the heterozygous allelic variants of the MDR1 gene at time of relapse/refractory disease

\begin{tabular}{|c|c|c|c|}
\hline & GG or TT & $G T$ & $P$ value \\
\hline \multicolumn{4}{|l|}{$M D R 1$} \\
\hline \multicolumn{4}{|l|}{ MRK16 } \\
\hline Median & 1.54 & 2.14 & .15 \\
\hline Range & $1.02-5.45$ & $1.18-5.55$ & \\
\hline $\mathrm{N}$ & 13 & 17 & \\
\hline \multicolumn{4}{|c|}{ MRK16/CD34 } \\
\hline Median & 1.88 & 2.68 & .22 \\
\hline Range & $1.49-4.90$ & $1.46-9.6$ & \\
\hline $\mathrm{N}$ & 7 & 7 & \\
\hline \multicolumn{4}{|l|}{ UIC2 } \\
\hline Median & 1.56 & 2.28 & .22 \\
\hline Range & $1.12-6.39$ & $0.99-5.24$ & \\
\hline$N$ & 13 & 17 & \\
\hline \multicolumn{4}{|c|}{ UIC2/CD34 } \\
\hline Median & 1.67 & 2.72 & .10 \\
\hline Range & $0.86-7.34$ & $1.69-5.15$ & \\
\hline $\mathrm{N}$ & 7 & 8 & \\
\hline \multicolumn{4}{|l|}{ PSC/Rho } \\
\hline Median & 1.08 & 1.14 & .30 \\
\hline Range & $0.81-1.85$ & $0.84-2.19$ & \\
\hline $\mathrm{N}$ & 13 & 17 & \\
\hline \multicolumn{4}{|c|}{ PSC/Rho/CD34 } \\
\hline Median & 1.21 & 1.42 & .40 \\
\hline Range & $1.07-1.72$ & $0.82-3.26$ & \\
\hline $\mathrm{N}$ & 9 & 9 & \\
\hline
\end{tabular}

For P-gp expression, the monoclonal antibodies MRK16 and UIC2 were used; fo $\mathrm{P}$-gp function, the PSC/Rho 123 retention ratio was used. In samples with more than $10 \%$ CD34 expression, the variables were also evaluated in the CD $34^{+}$subfraction of the blasts. The $P$ values indicate the differences between the homozygous and heterozygous patients.
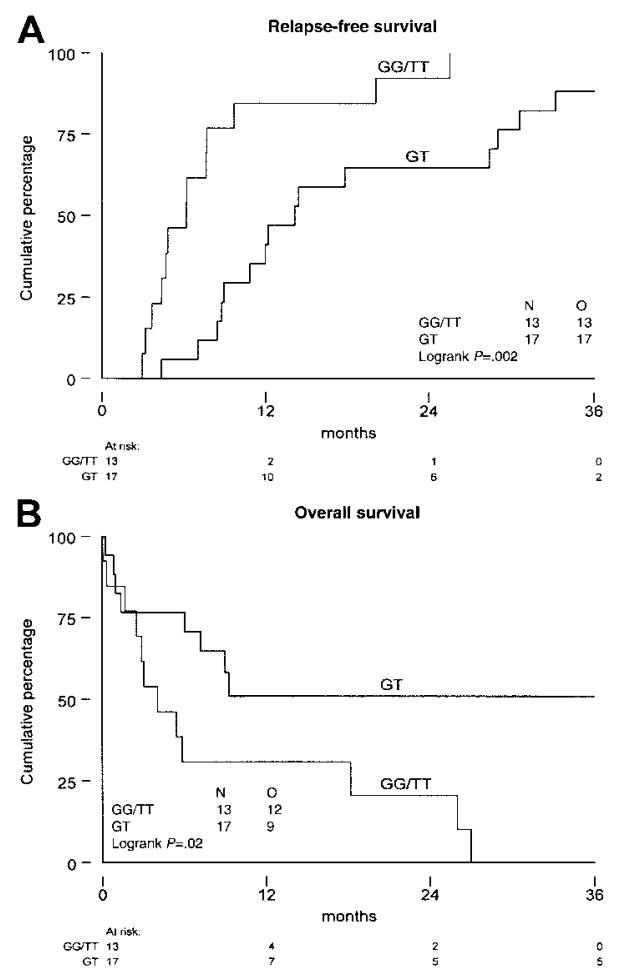

Figure 2. Survival of the patients with AML. Distinguishing patients that are homozygous (GG and TT) from patients that are heterozygous (GT) for the genetic polymorphism of position 2677 of the MDR1 gene. (A) Time from diagnosis until relapse/refractory disease. (B) Overall survival from relapse/refractory disease. $\mathrm{N}$ indicates number of patients investigated; $\mathrm{O}$, observed events. 
Table 5. Review of analyses of MDR1 expression in paired samples of patients with acute myeloid leukemia

\begin{tabular}{|c|c|c|c|c|c|}
\hline Author & Reference & $\begin{array}{l}\text { Number } \\
\text { of patients }\end{array}$ & $\begin{array}{l}\text { Expression } \\
\text { level } M D R 1\end{array}$ & $\begin{array}{c}\text { Age } \\
\text { category }\end{array}$ & $\begin{array}{c}\text { MDR1 expression } \\
\text { number in relapsed } \\
\text { vs de novo AML }\end{array}$ \\
\hline Gekeler & 35 & 1 & RNA & Children & Higher \\
\hline Beck & 36 & 1 & RNA & Children & Higher \\
\hline Guerci & 26 & 4 & Protein & Adults & Higher/equal \\
\hline Hart & 32 & 9 & RNA & Adults & Higher/lower \\
\hline Ino & 31 & 21 & Protein & Adults & Equal/lower \\
\hline Sato & 37 & 6 & RNA & Adults & Equal \\
\hline Ito & 30 & 10 & DNA & Adults & Equal \\
\hline Ito & 30 & 1 & RNA & Adults & Equal \\
\hline Ito & 30 & 10 & Protein & Adults & Higher/lower \\
\hline Kaczorowski & 34 & 1 & Protein & Children & Higher \\
\hline List & 29 & 17 & Protein & Adults & Lower \\
\hline Marie & 24 & 4 & RNA & Adults & Higher/equal \\
\hline Marie & 38 & 4 & RNA & Adults & Higher/lower/equal \\
\hline $\mathrm{Ma}$ & 41 & 2 & Protein & Adults & Higher/equal \\
\hline Musto & 23 & 2 & Protein & Adults & Higher \\
\hline Maslak & 27 & 5 & Protein & Adults & Higher \\
\hline Michieli & 28 & 7 & Protein & Adults & Higher/lower/equal \\
\hline Wood & 33 & 14 & Protein & Adults & Higher \\
\hline
\end{tabular}

shorter time from diagnosis to relapse $(P=.002)$ and a shorter overall survival from relapse $(P=.02)$ (Figure 2A,B).

\section{Discussion}

Clinical resistance to chemotherapy is a major problem in relapsed and/or refractory AML. MDR 1 expression in de novo AML is an adverse prognostic factor for CR and survival. ${ }^{3-7,11,22}$ It is conceivable that up-regulation of the MDR 1 gene is involved in the development of relapse and/or refractory disease, although this has not been investigated in paired analyses of respectable numbers of clinical samples of patients with AML. ${ }^{12}$ In the present study we analyzed whether clonal selection associated with the $M D R 1$ gene is involved in the development of relapsed AML. This is the first study that examined the allelic expression of MDR 1 in AML, using the genetic polymorphism of the $M D R 1$ gene. Our data show that there is no evidence of a $M D R 1$ gene-related clonal selection in the evolution of AML to relapse or refractory disease.

This is consistent with our observation that $\mathrm{P}$-gp expression and function did not increase from diagnosis to relapsed/refractory state. Several studies have reported a higher $M D R 1$ expression at time of relapse as compared to diagnosis. ${ }^{23-29}$ However, most studies compared patients who were not matched and studies in paired patient samples are scarce and generally they were performed in small numbers of patients. Most studies suggest an identical expression or even lower level of $M D R 1$ in relapsed/ refractory AML. ${ }^{29-32}$ Only the sequential analysis by Wood, who used immunocytochemistry techniques, showed a higher percentage of P-gp-positive samples in 14 relapsed patients with AML as compared with diagnosis. ${ }^{33}$ In pediatric patients, only 3 case reports are available. ${ }^{25,34,35}$ Therefore, although many studies have suggested that $M D R 1$ is up-regulated in relapsed and/or refractory AML, sequential studies do not support this theory (Table 5 and Table 6). The present analysis, which is the largest paired study in AML thus far, is an attempt to quantify MDR1 expression at genomic and protein level during the development toward resistant disease. In the 9 children and 21 adults studied, we did not find evidence that $M D R 1$, although being a strong prognostic factor at the time of diagnosis, is up-regulated at time of relapse and/or refractory disease in AML. We suggest that similar sequential studies of other mechanisms of drug resistance should be performed in patients with AML during the course of their disease in order to determine which drug resistance proteins are associated with clonal selection at relapse. In these studies it will be important to analyze children and younger adults separately from elderly patients with AML, since different mechanisms might be important in different age groups. ${ }^{6}$ Until now, the only study that analyzed $\mathrm{P}$-gp expression in a large group of children with AML showed that in contrast to adult AML, MDR1 expression was not of prognostic significance. ${ }^{39}$ In the present study no difference was found in P-gp expression and function between adults and children.

Our study emphasizes that it is important to study $M D R 1$ expression in clinical samples from patients with AML. In many cell lines, including even AML cell lines, MDR expression may be up-regulated as a direct response of cells to antineoplastic drugs.

Table 6. Review of $M D R 1$ expression in acute myeloid leukemia in nonpaired studies

\begin{tabular}{|c|c|c|c|c|c|c|}
\hline \multirow[b]{2}{*}{ Author } & \multirow[b]{2}{*}{ Reference } & \multicolumn{2}{|c|}{ Number of patients } & \multirow{2}{*}{$\begin{array}{l}\text { Expression } \\
\quad \text { level }\end{array}$} & \multirow[b]{2}{*}{ Age category } & \multirow{2}{*}{$\begin{array}{l}M D R 1 \text { expression in } \\
\text { relapsed vs de novo AML }\end{array}$} \\
\hline & & Dx & Relapse & & & \\
\hline Beck & 36 & 14 & 23 & RNA & Children & Higher \\
\hline Guerci & 26 & 69 & 10 & Protein & Adults & Higher \\
\hline List & 29 & 21 & 29 & Protein & Adults & Equal/lower \\
\hline Marie & 24 & 21 & 6 & RNA & Adults & Equal \\
\hline Musto & 23 & 8 & 7 & Protein & Adults & Lower \\
\hline Maslak & 27 & 18 & 19 & Protein & Adults and children & Higher \\
\hline Michieli & 28 & 38 & 21 & Protein & Adults & Higher \\
\hline
\end{tabular}


However, it seems apparent that this does not occur in patients with AML. ${ }^{40-48}$ This is the first analysis of the functional significance of the genetic polymorphism of $M D R 1$ in highly purified samples of AML. P-gp function and expression were similar in any one of the specific allelic variants (G, T, and GT). These findings suggest that the genetic polymorphism of the MDR 1 gene (at position 2677) lacks functional importance in AML. However, we found that patients with homozygous expression of the MDRl gene (GG or TT) had a shorter time to relapse and overall survival from relapse/refractory disease than heterozygous patients. This finding warrants further studies on the role of genetic polymorphisms of $M D R 1$ in AML.

$M D R 1$ expression at diagnosis is a strong adverse prognostic factor in AML. However, our sequential analysis reveals that there is no higher function or expression of P-gp at relapse or refractory disease, and that specific allelic expression is not related to increased P-gp expression or function. Since no loss of a specific $M D R 1$ allele has been observed in these patients with AML, MDR 1 gene-related clonal selection plays no role in the development of resistant disease. These data suggest that mechanisms other than MDR 1 might be responsible for the development of clinical resistance in these patients.

\section{Acknowledgment}

We thank the Dutch Childhood Leukemia Study Group for bone marrow samples of pediatric patients with AML.

\section{References}

1. Campos L, Guyotat D, Archimbaud E, et al. Clinical significance of multidrug resistance P-glycoprotein expression on acute non-lymphoblastic leukemia cells at diagnosis. Blood. 1992;79: 473-476.

2. Del Poeta G, Stasi R, Venditti A, et al. Prognostic value of cell marker analysis in de novo acute myeloid leukemia. Leukemia. 1994;8:388-394.

3. Del Poeta G, Stasi R, Aronica G, et al. Clinical relevance of P-glycoprotein expression in de novo acute myeloid leukemia. Blood. 1996;87: 1997-2004.

4. Leith CP, Kopecky KJ, Godwin J, et al. Acute myeloid leukemia in the elderly: assessment of multidrug resistance (MDR1) and cytogenetics distinguishes biologic subgroups with remarkably distinct responses to standard chemotherapy: a Southwest Oncology Group study. Blood. 1997; 89:3323-3329.

5. Van den Heuvel-Eibrink MM, van der Holt B, te Boekhorst PA, et al. MDR 1 expression is an independent prognostic factor for response and survival in de novo acute myeloid leukaemia. $\mathrm{Br} \mathrm{J}$ Haematol. 1997;99:76-83.

6. Van den Heuvel-Eibrink MM, Sonneveld P, Pieters $\mathrm{R}$. The prognostic significance of membrane transport-associated multidrug resistance (MDR) proteins in leukemia. Int $\mathrm{J}$ Clin Pharmacol Ther. 2000;38:94-110.

7. Willman $\mathrm{CL}$. The prognostic significance of the expression and function of multidrug resistance transporter proteins in acute myeloid leukemia: studies of the Southwest Oncology Group Leukemia Research Program. Semin Hematol. 1997; 34(4 suppl 5):25-33.

8. Senent L, Jarque I, Martin G, et al. P-glycoprotein expression and prognostic value in acute myeloid leukemia. Haematologica. 1998;83:783-787.

9. Legrand O, Simonin G, Zittoun R, Marie JP. Both $\mathrm{P}$-gp and MRP contribute to drug resistance in AML. Blood. 1999;94:1046-1056.

10. Legrand O, Simonin G, Perrot JY, Zittoun R Marie JP. P-gp and MRP activities using calcein-AM are prognostic factors in adult acute myeloid leukemia patients. Blood. 1998;91:44804488.

11. Michieli M, Damiani D, Ermacora A, et al. P-glycoprotein, lung resistance-related protein and multidrug resistance associated protein in de novo acute non-lymphocytic leukaemias: biological and clinical implications. Br J Haematol. 1999, 104:328-335

12. Mickley LA, Lee JS, Weng Z, et al. Genetic polymorphism in MDR-1: a tool for examining allelic expression in normal cells, unselected and drug selected cell lines, and human tumors. Blood. 1998;91:1749-1756.

13. Mickley LA, Spengler BA, Knutsen TA, Biedler JL Fojo T. Gene rearrangement: a novel mechanism for MDR-1 gene activation. J Clin Invest. 1997; 99:1947-1957.

14. Bennett JM, Catovsky D, Daniel MT, et al. Proposed revised criteria for the classification of acute myeloid leukemia: a report of the FrenchAmerican-British Cooperative Group. Ann Intern Med. 1985;103:620-625.

15. Mitelman F, ed. ISCN 1991: Guidelines for Cancer Cytogenetics: Supplement to an International System for Human Cytogenetic Nomenclature. Basel, Switzerland: Karger; 1991.

16. Lowenberg B, van Putten WL, Touw IP, Delwel R, Santini V. Autonomous proliferation of leukemic cells in vitro as a determinant of prognosis in adult acute myeloid leukemia. N Engl J Med. 1993:328:614-619.

17. Sugawara I, Kataoka I, Morishita Y, et al. Tissue distribution of P-glycoprotein encoded by a multidrug-resistant gene as revealed by a monoclonal antibody, MRK 16. Cancer Res. 1988;48:19261929.

18. Mechetner EB, Roninson IB. Efficient inhibition of P-glycoprotein-mediated multidrug resistance with a monoclonal antibody. Proc Natl Acad Sci U S A. 1992;89:5824-5828.

19. Chaudhary PM, Roninson IB. Expression and activity of P-glycoprotein, a multidrug efflux pump, in human hematopoietic stem cells. Cell. 1991;66:85-94.

20. Ludescher C, Thaler J, Drach D, et al. Detection of activity of $\mathrm{P}$-glycoprotein in human tumour samples using rhodamine 123. $\mathrm{Br} \mathrm{J}$ Haematol. 1992;82:161-168

21. Dalton WS, Durie BG, Alberts DS, Gerlach JH, Cress AE. Characterization of a new drug-resistant human myeloma cell line that expresses $\mathrm{P}$ glycoprotein. Cancer Res. 1986;46:5125-5130.

22. Hunault M, Zhou D, Delmer A, et al. Multidrug resistance gene expression in acute myeloid leukemia: major prognostic significance for in vivo drug resistance to induction treatment. Ann $\mathrm{He}$ matol. 1997;74:65-71.

23. Musto P, Cascavilla N, Di Renzo N, et al. Clinical relevance of immunocytochemical detection of multidrug resistance associated P-glycoprotein in hematologic malignancies. Tumori. 1990;76:353-359.

24. Marie JP, Zittoun R, Sikic BI. Multidrug resistance (mdr1) gene expression in adult acute leukemias: correlations with treatment outcome and in vitro drug sensitivity. Blood. 1991;78:586-592.

25. Beck WT, Grogan TM, Willman CL, et al. Methods to detect P-glycoprotein-associated multidrug resistance in patients' tumors: consensus recommendations. Cancer Res. 1996;56:3010-3020.

26. Guerci A, Merlin JL, Missoum N, et al. Predictive value for treatment outcome in acute myeloid leukemia of cellular daunorubicin accumulation and P-glycoprotein expression simultaneously deter- mined by flow cytometry. Blood. 1995;85:21472153.

27. Maslak P, Hegewisch-Becker S, Godfrey L, Andreeff M. Flow cytometric determination of the multidrug-resistant phenotype in acute leukemia. Cytometry. 1994;17:84-93.

28. Michieli M, Giacca M, Fanin R, Damiani D, Geromin A, Baccarani M. Mdr-1 gene amplification in acute lymphoblastic leukaemia prior to antileukaemic treatment. Br J Haematol. 1991;78: 288-289.

29. List AF. Role of multidrug resistance and its pharmacological modulation in acute myeloid leukemia. Leukemia. 1996;10:937-942.

30. Ito $\mathrm{Y}$, Tanimoto $\mathrm{M}$, Kumazawa $\mathrm{T}$, et al. Increased P-glycoprotein expression and multidrug-resistant gene (mdr1) amplification are infrequently found in fresh acute leukemia cells: sequential analysis of 15 cases at initial presentation and relapsed stage. Cancer. 1989;63:1534-1538.

31. Ino $\mathrm{T}$, Miyazaki $\mathrm{H}$, Isogai $\mathrm{M}$, et al. Expression of P-glycoprotein in de novo acute myelogenous leukemia at initial diagnosis: results of molecular and functional assays, and correlation with treatment outcome. Leukemia. 1994;8:1492-1497.

32. Hart SM, Ganeshaguru K, Hoffbrand AV, Prentice $H G$, Mehta AB. Expression of the multidrug resistance-associated protein (MRP) in acute leukaemia. Leukemia. 1994;8:2163-2168.

33. Wood P, Burgess R, MacGregor A, Yin JA. P-glycoprotein expression on acute myeloid leukaemia blast cells at diagnosis predicts response to chemotherapy and survival. Br J Haematol. 1994;87: 509-514.

34. Kaczorowski S, Ochoka M, Aleksandrowicz R, Kaczorowska M, Matysiak M, Karwacki M. Expression of P-glycoprotein in children and adults with leukemia: correlation with clinical outcome. In: Hiddeman et al, eds. Acute Leukemias V: Experimental Approaches and Management of Refractory Diseases. Berlin, Heidelberg: SpringerVerlag; 1996:101-107.

35. Gekeler V, Frese G, Noller A, et al. Mdr1/P-glycoprotein, topoisomerase, and glutathione-S-transferase pi gene expression in primary and relapsed state adult and childhood leukaemias. $\mathrm{Br}$ Cancer. 1992;66:507-517.

36. Beck J, Handgretinger R, Klingebiel T, et al. Expression of PKC isozyme and MDR-associated genes in primary and relapsed state AML. Leukemia. 1996;10:426-433.

37. Sato H, Preisler H, Day R, et al. MDR1 transcript levels as an indication of resistant disease in acute myelogenous leukaemia. $\mathrm{Br} \mathrm{J}$ Haematol. 1990;75:340-345.

38. Marie JP, Faussat-Suberville AM, Zhou D, Zittoun R. Daunorubicin uptake by leukemic cells: correlations with treatment outcome and mdr1 expression. Leukemia. 1993;7:825-831. 
39. Sievers EL, Smith FO, Woods WG, et al. Cell surface expression of the multidrug resistance P-glycoprotein (P-170) as detected by monoclonal antibody MRK-16 in pediatric acute myeloid leukemia fails to define a poor prognostic group a report from the Childrens Cancer Group. Leukemia. 1995;9:2042-2048.

40. Gekeler V, Frese G, Diddens H, Probst H. Expression of a P-glycoprotein gene is inducible in a multidrug resistant human leukemia cell line. Biochem Biophys Res Commun. 1988;155:754-760.

41. Ma DD, Scurr RD, Davey RA, et al. Detection of a multidrug resistant phenotype in acute non-lymphoblastic leukaemia. Lancet. 1987;1:135-137.

42. Baas F, Jongsma AP, Broxterman HJ, et al. NonP-glycoprotein mediated mechanism for multi- drug resistance precedes P-glycoprotein expression during in vitro selection for doxorubicin resistance in a human lung cancer cell line. Cancer Res. 1990;50:5392-5398.

43. Goldstein LJ, Galski H, Fojo A, et al. Expression of a multidrug resistance gene in human cancers. J Natl Cancer Inst. 1989;81:116-124.

44. Chaudhary PM, Roninson IB. Induction of multidrug resistance in human cells by transient exposure to different chemotherapeutic drugs. J Natl Cancer Inst. 1993;85:632-639.

45. Gekeler V, Beck J, Noller A, et al. Drug-induced changes in the expression of MDR-associated genes: investigations on cultured cell lines and chemotherapeutically treated leukemias. Ann $\mathrm{He}$ matol. 1994;69(suppl 1):S19-S24.
46. Brock I, Hipfner DR, Nielsen BS, et al. Sequential coexpression of the multidrug resistance genes MRP and mdr1 and their products in VP-16 (etoposide)-selected $\mathrm{H} 69$ small cell lung cancer cells. Cancer Res. 1995;55:459-462.

47. Matsumoto $\mathrm{Y}$, Takano H, Fojo T. Cellular adaptation to drug exposure: evolution of the drugresistant phenotype. Cancer Res. 1997;57: 5086-5092

48. Knutsen T, Mickley LA, Ried T, et al. Cytogenetic and molecular characterization of random chromosomal rearrangements activating the drug resistance gene, MDR1/P- glycoprotein, in drug-selected cell lines and patients with drug refractory ALL. Genes Chromosomes Cancer. 1998;23:44-54. 